\title{
Effect of Processing Methods on Mineral Contents of Selected Lentils (Lens Culinuris) Varieties (Derash and Alemaya) Grown in Ethiopia
}

\author{
Daniel Asfaw ${ }^{1 *} \quad$ Asnake Fikre ${ }^{2}$ \\ 1.Department of Food Science and Nutrition, Wollega University \\ 2.International Crops Research Institute for Semi Arid Tropics
}

\begin{abstract}
Mineral contents of legumes showed significant reduction during the process of cooking due to leaching of minerals into cooking water. The aim of this study was to investigate the effects of various processing methods (autoclaving, boiling, dehulling, germinating and soaking) on mineral contents of the two selected lentil varieties (Alemaya and Derash). The present study revealed that processing methods affect the mineral contents of lentils. Germinating process was the least reduction of $\mathrm{Zn}, \mathrm{Fe}$ and $\mathrm{Ca}$ by $4.52,4.23$ and $0.55 \%$, however, dehulling process was the highest reduction by $25.91,19.14$ and $9.56 \%$, respectively.
\end{abstract}

Keywords: Lentil, Alemaya variety, Derash variety, Mineral contents, Processing methods

DOI: $10.7176 / \mathrm{FSQM} / 88-03$

Publication date:July $31^{\text {st }} 2019$

\section{Introduction}

Lentil is an excellent source of macronutrients $(\mathrm{P}, \mathrm{K}, \mathrm{Ca}, \mathrm{Mg}$, and $\mathrm{Na}$ ), micronutrients ( $\mathrm{Fe}, \mathrm{Zn}, \mathrm{Cu}$, and $\mathrm{Mn}$ ), and trace elements ( $\mathrm{Al}, \mathrm{Cr}, \mathrm{Ni}, \mathrm{Pb}, \mathrm{Co}, \mathrm{Se}, \mathrm{Mo})$. Red lentils provide three different minerals: calcium, iron and potassium. The iron content of 100 grams of dry, whole red lentils is $7.3 \mathrm{mg}$, the potassium content is $1,135 \mathrm{mg}$ and the calcium content is $97.3 \mathrm{mg}$. Dil and Pushparajah, (2011) reported that mineral concentrations in lentils vary with soil mineral content. Comparison of international lentil samples showed high lentil Fe concentrations from Syria $\left(63 \mathrm{mg} \mathrm{kg}^{-1}\right)$, Turkey $\left(60 \mathrm{mgkg}^{-1}\right)$, USA $\left(56 \mathrm{mgkg}^{-1}\right)$, and Nepal $\left(50 \mathrm{mgkg}^{-1}\right)$, and the lower concentrations from Australia $\left(46 \mathrm{mgkg}^{-1}\right)$ and Morocco $\left(42 \mathrm{mg} \mathrm{kg}^{-1}\right)$. The total Fe concentrations in lentils ranged from 73 to $90 \mathrm{mg} \mathrm{Fe} \mathrm{kg}{ }^{-1}$ and $\mathrm{Zn}$ concentrations in lentils ranged from $44-54 \mathrm{mgkg}^{-1}$.

The iron is present in significant quantity in lentils (Padoani et al., 2007; Ryan et al., 2007). In addition, lentils contain $\mathrm{Zn}$ which ranges between 3.2 and $6.3 \mathrm{mg} / 100 \mathrm{~g}$. The content of $\mathrm{Fe}, \mathrm{Ca}$ and $\mathrm{Zn}$ in whole lentils were $7.5 \mathrm{mg} / 100 \mathrm{~g}, 56 \mathrm{mg} / 100 \mathrm{~g}$ and $4.8 \mathrm{mg} / 100 \mathrm{~g}$ respectively (USDA 2010). Also the $\mathrm{Fe}, \mathrm{Ca}$ and $\mathrm{Zn}$ content of split lentils were $7.6 \mathrm{mg} / 100 \mathrm{~g}, 41 \mathrm{mg} / 100 \mathrm{~g}$ and $3.9 \mathrm{mg} / 100 \mathrm{~g}$ respectively.

Mineral contents of legumes also showed significant reduction (18.99-39.50\%) during the process of cooking due to leaching of minerals into cooking water (Nuzhat et al., 2008). Soaking cereal and most legume flours (but not whole grains or seeds) in water can result in passive diffusion of water-soluble $\mathrm{Na}, \mathrm{K}$, or Mg phytate, which can then be removed by decanting the water (Hotz and Gibson, 2001; Perlas and Gibson, 2002). Wang and Hatcher, (2009) reported that dehulling resulted in a significant increase in $\mathrm{K}$ and $\mathrm{P}$ however, a significant decrease in $\mathrm{Ca}$, $\mathrm{Cu}, \mathrm{Fe}, \mathrm{Mg}$ and $\mathrm{Mn}$ content was observed. Wang and Hatcher, (2009) also reported that cooking lentils in boiling water significantly increased $\mathrm{Ca}, \mathrm{Cu}$ and $\mathrm{Mn}$ content, whereas reduced $\mathrm{Fe}, \mathrm{K}, \mathrm{Mg}, \mathrm{P}$ and $\mathrm{Zn}$ were observed. However, there is a research gap on the effect of processing methods on lentil varieties produced in Ethiopia. Therefore, the objective of this study was to determine the effect of processing methods on mineral contents of the selected varieties of lentil.

\section{Materials and Methods}

\subsection{Experimental Location}

The study was conducted at Haramaya University. Chemical analysis such as crude protein, crude fat, crude fiber, ash content, moisture content and anti-nutritional content, were determined at School of Food Science, Post Harvest Technology and Processing Engineering laboratory. Mineral analysis was carried out at School of Food Science, Post Harvest Technology and Processing Engineering and Soil laboratories.

\subsection{Experimental Materials}

The samples for investigation i.e $6 \mathrm{~kg}$ seed of each of the lentil varieties Derash and Alemaya, were collected from Bishoftu Agricultural Research Centre (BARC), national legumes improvement program.

\subsection{Experimental Design}

Completely randomized design (CRD) with a $2 \times 6$ factorial experiment with three replication was implemented. Two selected lentil varieties, Derash and Alemaya, were tested under five different processing methods (dehulling, 
soaking, germination, autoclaving, and boiling) with one untreated sample (control) for each variety (Table 1).

Table 1. Experimental plan

\begin{tabular}{ccc}
\hline Factor-2, Processing & \multicolumn{2}{c}{ Factor -1, Variety } \\
\cline { 2 - 3 } & $\mathrm{De}$ & $\mathrm{Al}$ \\
$\mathrm{Au}$ & $\mathrm{AuDe}$ & $\mathrm{AuAl}$ \\
$\mathrm{Bo}$ & $\mathrm{BoDe}$ & $\mathrm{BoAl}$ \\
$\mathrm{Dh}$ & $\mathrm{DhDe}$ & $\mathrm{DhAl}$ \\
$\mathrm{Ge}$ & $\mathrm{Ge} \mathrm{De}$ & $\mathrm{Ge} \mathrm{Al}$ \\
$\mathrm{Ra}$ & $\mathrm{RaDe}$ & $\mathrm{RaAl}$ \\
$\mathrm{So}$ & $\mathrm{SoDe}$ & $\mathrm{SoAl}$ \\
\hline
\end{tabular}

Where $\mathrm{Al}=$ Alemaya variety, $\mathrm{De}=$ Derash variety, $\mathrm{Au}=$ Autoclaving, $\mathrm{Bo}=$ Boiling, $\mathrm{Dh}=$ Dehulling, $\mathrm{Ge}=$ Germinating, $\mathrm{Ra}=\mathrm{Raw} /$ Control sample, So $=$ Soaking

\subsection{Sample Preparation}

Samples of each of Derash and Alemaya lentil varieties were cleaned manually by removing any foreign material, damaged and broken seeds. The seeds were processed by dehulling, soaking, germination, boiling and autoclaving. The processed samples including the control sample were dried in an oven at $50^{\circ} \mathrm{C}$ for about $24 \mathrm{hr}$. All samples were milled by laboratory miller (cyclo sample mill model no: 3010-081p) and pass through $75 \mu \mathrm{m}$ sieve. The flours were packed in moisture proof plastic bags and stored in airtight tin containers at $4^{\circ} \mathrm{C}$ until required for analysis.

\subsection{Processing Techniques}

\subsubsection{Direct grinding}

Cleaned seed of $600 \mathrm{~g}$ each of Derash and Alemaya varieties were directly ground by mill.

\subsubsection{Dehulling}

A $600 \mathrm{~g}$ cleaned seed of each of Derash and Alemaya varieties were dehulled by pestle and mortar. The hull was separated using traditional tool (gundoo) from split seeds. The split lentil was milled as indicated above.

\subsubsection{Soaking}

The $600 \mathrm{~g}$ of clean seed each of the two lentil varieties were soaked in distilled water for $12 \mathrm{hr}$ at room temperature (Osama et al., 1985). The soaked samples were drained and rinsed three times with $600 \mathrm{ml}$ distilled water. The samples were oven dried at $50^{\circ} \mathrm{C}$ for $24 \mathrm{hr}$. The dried samples were milled and passed through $75 \mu \mathrm{m}$ sieve. The flours were packed in moisture proof plastic bags and stored in airtight tin containers at $4^{\circ} \mathrm{C}$ until required for analysis.

\subsubsection{Autoclaving}

The $600 \mathrm{~g}$ cleaned seed each of the two lentil variety were soaked in distilled water $(1: 10, \mathrm{w} / \mathrm{v})$ for $12 \mathrm{hr}$ at room temperature $\left(25^{\circ} \mathrm{C}\right)$. The soaked samples were drained and rinsed three times with $600 \mathrm{ml}$ distilled water. The rinsed soaked samples were autoclaved at $121^{\circ} \mathrm{C}$ under $15 \mathrm{lb}$ pressure in distilled water $(1: 10, \mathrm{w} / \mathrm{v})$ until they became soft when felt between the fingers (35 min) (Hefnawy, 2011) and immediately dried in oven drying at $50^{\circ} \mathrm{C}$ for $24 \mathrm{hr}$. The dried sample was milled and passes through $75 \mu \mathrm{m}$ sieve. The flours were packed in moisture proof plastic bags and stored in airtight tin containers at $4^{\circ} \mathrm{C}$ until required for analysis.

\subsubsection{Germination}

The $600 \mathrm{~g}$ seed of each of Derash and Alemaya varieties were cleaned and soaked in distilled water at room temperature for $12 \mathrm{hr}$. The soaked samples were drained and rinsed three times with $600 \mathrm{ml}$ distilled water. The water was drained off and the samples covered in trays lined with absorbent paper and left to germinate for $72 \mathrm{hr}$ (Mashair et al., 2008). At the end of the germination process, the samples were oven dried at $50^{\circ} \mathrm{C}$ for $24 \mathrm{hr}$, milled and passed through $75 \mu \mathrm{m}$ sieve. The flours were packed in moisture proof plastic bags and stored in airtight tin containers at $4^{\circ} \mathrm{C}$ until required for analysis.

\subsubsection{Boiling}

The $600 \mathrm{~g}$ cleaned samples of each of the two varieties were soaked in distilled water $(1: 10, \mathrm{w} / \mathrm{v})$ for $12 \mathrm{hr}$ at room temperature $\left(25^{\circ} \mathrm{C}\right)$. The soaked seeds were drained and rinsed three times with $600 \mathrm{ml}$ distilled water. The samples were then boiled in distilled water in the ratio of 1:10 (w/v) until they became soft when felt between the fingers (90 min) (Hefnawy, 2011) and immediately dried in oven at $50^{\circ} \mathrm{C}$ for $24 \mathrm{hr}$. The dried samples were milled and passed through $75 \mu \mathrm{m}$ sieve. The flours were packed in moisture proof plastic bags and stored in airtight tin containers at $4^{\circ} \mathrm{C}$ until required for analysis.

\subsection{Minerals Analysis}

\subsubsection{Calcium}

The calcium content was determined by atomic absorption spectrophotometer (AACC, 2000). Calcium content was calculated with the following formula 


$$
\mathrm{Ca}(\mathrm{ppm})=\frac{\mathrm{C} \times 100}{\mathrm{~S}}
$$

Where: $\mathrm{C}$ is the concentration of the sample from plot of absorption in $\mu \mathrm{g} / \mathrm{ml}$ and s sample mass $(\mathrm{g})$.

\subsubsection{Iron}

Iron content was determined by Atomic Absorption Spectrophotometer (AACC, 2000).

$$
\mathrm{Fe}(\mathrm{ppm})=\frac{(\mu \mathrm{g} / \mathrm{mL}) \times 100}{\text { Sample } \operatorname{mass}(\mathrm{db})}
$$

Where: $\mu \mathrm{g} / \mathrm{mL}$ is the absorbance reading concentration

\subsubsection{Zinc}

Zinc content was determined by Atomic Absorption Spectrophotometer (AACC, 2000). Zinc content was calculated by the following formula:

$$
\mathrm{Zn}(\mathrm{ppm})=\frac{(\mu \mathrm{g} / \mathrm{mL}) \times 100}{\text { Sample mass }(\mathrm{db})}
$$

Where: $\mu \mathrm{g} / \mathrm{mL}$ is the absorbance reading concentration

\subsection{Statistical Analysis}

Mineral content of the raw and processed samples were statistically analyzed using analysis of variance (ANOVA) and least significant difference (LSD). The statistical package used was (SAS Institute and Cary, NC). Significant differences were determined at the $\mathrm{P} \leq 0.05$ level using Fisher LSD to identify significant differences among mean effects of the varieties and processing methods.

\section{Results and Discussions}

\subsection{Mineral contents in Raw Lentil Varieties}

Zinc, iron and calcium contents of the two lentil varieties were significantly $(\mathrm{P} \leq 0.05)$ different from each other (Table 2.). The amount of zinc, iron and calcium were $52.94,67.16$ and $813.26 \mathrm{mg} / \mathrm{kg}$ for Alemaya variety and $41.77,53.94$ and $872.59 \mathrm{mg} / \mathrm{kg}$ for Derash variety, respectively. Except calcium both minerals in the present study were higher in Alemaya variety than in Derash variety. The values of iron obtained from this finding are less than that reported by El-Adawy et al. (2003) in variety Giza 9 which is $85.00 \mathrm{mg} / \mathrm{kg}$. However, the calcium contents obtained were greater than that obtained in Giza 9 lentil variety which is $760.00 \mathrm{mg} / \mathrm{kg}$. Similarly the result of zinc obtained from this finding is greater than that obtained in other different lentil varieties which ranged from 12.8 to $38.9 \mathrm{mg} / \mathrm{kg}$ (Ozer and Kaya, 2010).

Table 2. Mineral composition of selected lentil varieties

\begin{tabular}{lccc}
\hline Variety & \multicolumn{3}{c}{ Mineral content $(\mathrm{db}, \mathrm{mg} / \mathrm{kg})$} \\
$\mathrm{Zn}$ & $\mathrm{Fe}$ & $\mathrm{Ca}$ \\
\hline $\mathrm{Al}$ & $52.94 \pm 0.08^{\mathrm{a}}$ & $67.16 \pm 0.10^{\mathrm{a}}$ & $813.26 \pm 0.20^{\mathrm{b}}$ \\
$\mathrm{De}$ & $41.77 \pm 0.18^{\mathrm{b}}$ & $53.94 \pm 0.03^{\mathrm{b}}$ & $872.59 \pm 0.10^{\mathrm{a}}$ \\
\hline $\mathrm{CV}$ & 0.51 & 0.21 & 0.03 \\
$\mathrm{LSD}$ & 0.54 & 0.28 & 0.62 \\
\hline
\end{tabular}

$\mathrm{Al}=$ Alemaya variety, $\mathrm{De}=$ Derash variety, $\mathrm{CV}=$ coefficient of variation; $\mathrm{LSD}=$ least significant difference; values followed by the same letter in a column are not different at $5 \%$ level of significance.

\subsection{Effect of Processing Methods on Mineral Contents}

\subsubsection{Zinc}

Processing methods resulted in significant $(\mathrm{P} \leq 0.05)$ effect on zinc content (Table 3.). The maximum $(47.35 \mathrm{mg} / \mathrm{kg})$ average value was found in the raw sample and the minimum $(35.08 \mathrm{mg} / \mathrm{kg})$ was found in dehulled sample. According to this finding, the zinc content reduced in dehulled, boiled, autoclaved, soaked and germinated samples by $25.91,16.56,13.79,7.41$ and $4.52 \%$, respectively. These reductions may be due to the minerals leached from the lentils' seeds into the distilled water at different rates during soaking, boiling and autoclaving. The reduction of zinc in dehulled samples might be due to the removal of seed coat during processing. 
Table 3. Average mineral content of lentil samples processed by different methods

\begin{tabular}{ccccccc}
$\begin{array}{c}\text { Processing } \\
\text { Methods }\end{array}$ & $\begin{array}{c}\mathrm{Zn} \\
(\mathrm{mg} / \mathrm{kg}, \mathrm{db})\end{array}$ & $\begin{array}{c}\text { reduction } \\
(\%)\end{array}$ & $\begin{array}{c}\mathrm{Fe} \\
(\mathrm{mg} / \mathrm{kg}, \mathrm{db})\end{array}$ & $\begin{array}{c}\text { reduction } \\
(\%)\end{array}$ & $\begin{array}{c}\mathrm{Ca} \\
(\mathrm{mg} / \mathrm{kg}, \mathrm{db})\end{array}$ & $\begin{array}{c}\text { reduction } \\
(\%)\end{array}$ \\
\hline $\mathrm{Au}$ & $40.82 \pm 2.23^{\mathrm{d}}$ & 13.79 & $52.21 \pm 4.92^{\mathrm{d}}$ & 13.77 & $812.99 \pm 12.14^{\mathrm{c}}$ & 3.55 \\
$\mathrm{Bo}$ & $39.51 \pm 2.93^{\mathrm{e}}$ & 16.56 & $54.89 \pm 3.99^{\mathrm{c}}$ & 9.35 & $802.91 \pm 16.56^{\mathrm{d}}$ & 4.75 \\
$\mathrm{Dh}$ & $35.08 \pm 1.76^{\mathrm{f}}$ & 25.91 & $48.96 \pm 5.51^{\mathrm{e}}$ & 19.14 & $762.38 \pm 20.28^{\mathrm{e}}$ & 9.56 \\
$\mathrm{Ge}$ & $45.21 \pm 2.76^{\mathrm{b}}$ & 4.52 & $57.99 \pm 3.52^{\mathrm{b}}$ & 4.23 & $838.30 \pm 14.18^{\mathrm{ab}}$ & 0.55 \\
$\mathrm{Ra}$ & $47.35 \pm 2.50^{\mathrm{a}}$ & --- & $60.55 \pm 2.96^{\mathrm{a}}$ & --- & $842.93 \pm 13.27^{\mathrm{a}}$ & -- \\
$\mathrm{So}$ & $43.84 \pm 2.39^{\mathrm{c}}$ & 7.41 & $56.47 \pm 3.75^{\mathrm{bc}}$ & 6.74 & $832.23 \pm 14.95^{\mathrm{b}}$ & 1.27 \\
\hline $\mathrm{CV}$ & 2.41 & \multicolumn{7}{c}{3.90} & 0.81 & \\
$\mathrm{LSD}$ & 0.69 & 1.47 & 4.49 & \\
\hline
\end{tabular}

$\mathrm{Au}=$ authoclaving, $\mathrm{Bo}=$ boiling, $\mathrm{Dh}=$ dehulling, $\mathrm{Ge}=$ germinating, $\mathrm{Ra}=$ raw, $\mathrm{So}=$ soaking

$\mathrm{CV}=$ coefficient of variation; $\mathrm{LSD}=$ least significance difference; values are mean values followed by the same letter in column are not different at $5 \%$ level of significance.

\subsubsection{Iron}

The result of these finding showed that processing methods had significant $(\mathrm{P} \leq 0.05)$ effect on the iron contents of samples (Table 3). The average values of raw, autoclaved, boiled, dehulled, germinated and soaked samples were $60.55,52.21,54.89,48.96,57.99$ and $56.47 \mathrm{mg} / \mathrm{kg}$, respectively. Processing reduced the content of iron by 19.14 , $13.77,9.35,6.74$ and $4.23 \%$ in dehulled, autoclaved, boiled, soaked and germinated samples, respectively. The reduction of iron content might be attributed to leaching during soaking, cooking after soaking and removal of seed coat of lentil samples. These finding agreed with the report of Mubarak, (2005) on the effect of dehulling, soaking, germinating, boiling, autoclaving and microwave cooking of mung bean seeds. However, El-Adawy et al. (2003) reported that germination of mung bean, pea and lentil increased the content of iron. Haytowitz and Matthews, (1983) reported that cooking in boiling water caused great losses of Fe (8\%). Hatcher, (2009) reported that dehulling (removal of seed coat) resulted in a significant decrease in iron content.

\subsubsection{Calcium}

Processing method had significant $(\mathrm{P} \leq 0.05)$ effect on calcium content of lentils (Table 3.). Processing decreased the content of calcium from maximum $(842.93 \mathrm{mg} / \mathrm{kg})$ to a minimum $(762.38 \mathrm{mg} / \mathrm{kg})$ in raw and dehulled sample, respectively. Processing methods reduced the contents of calcium by $9.56,4.75,3.55,1.27$ and $0.55 \%$ in dehulled, boiled, autoclaved, soaked and germinated samples, respectively. The reduction of calcium due to germination disagreed with the finding of El-Adawy et al. (2003) on lentil, mung bean and pea which increased after germination. However, agreed with Mubarak, (2005) who reported on reduction of calcium content during dehulling, boiling, germinating, autoclaving, soaking and microwave cooking in mung bean seeds. The reduction of calcium during germination could be due to leaching during soaking that takes place prior to germination.

\section{Conclusion and Recommendation}

\subsection{Conclusion}

The mineral contents of the lentils' samples were reduced in varied degree by all processing methods indicated in this finding. Dehulling process was the highest reduction whereas germinating process was the least reduction of mineral contents.

\subsection{Recommendation}

The current study observed the effect of different processing methods on mineral contents. This finding recommends that:

$\checkmark$ Instead of dehulling, using germination during lentil processing to different end products.

$\checkmark$ Study on the effect of modern processing techniques on the mineral contents of lentil varieties in Ethiopia.

\section{References}

AACC, (2000) Official methods of analysis of AACC. VIEW METHOD. 40-75.01 Determination of Minerals by Inductively Coupled Plasma Spectroscopy.

Dil Thavarajah and Pushparajah, 2011. Lentils (Lens culinaris L): A Whole Food Solution for Micronutrient Malnutrition.

El-Adawy TA, Rahma EH, El-Bedawey AA, El-Beltagy AE. 2003. Nutritional potential and functional properties of ger-minated mung bean, pea and lentil seeds. Plant Foods Hum Nutr58:1-13

Haytowitz, D.B., Matthews, R.H., 1983. Effect of cooking on nutrient retention of legumes. Cereal Food World, 28(6):

Hefnawy, 2011. Effect of processing methods on nutritional composition and anti-nutritional factors in lentils 
(Lens culinaris). Annals of Agricultural Sciences. Volume 56, Issue 2, Pages 57-61

Hotz C, Gibson RS. Assessment of home-based processing methods to reduce phytate content and phytate/zinc molar ratios of white maize (Zea mays). J Agric Food Chem. 2001;49:692-8.

Mashair A. Suliman, Mohamed M. Eltayeb, Elfadil E. Babiker, Abdelmoneim I. Mustafa and Abullahi H. El Tinay, 2008. Effect of Sprouting on Chemical Composition and Amino Acid Content of Sudanese Lentil Cultivars. Journal of Applied Sciences 8(12):2337 - 2340.

Mubarak, 2005. Nutritional Composition and Anti-nutritional Factors of Mung bean Seeds (Phaseolusaureus) as Affected by Some Home Traditional Processes. www.elsevier.com/locate/foodchem. Food Chemistry 89, pp489-495

Nuzhat Huma, Faqir Muhammad Anjum, Samreen Sehar, Muhammad Issa Khan and Shahzad Hussain Effect of soaking and cooking on nutritional quality and safety of Legumes, Nutrition \& Food Science Vol. 38 No. 6 , 2008, pp574

Ozer and F.Kaya, 2010. Physical, chemical and physichochemical properties of some lentil varieties. Journal of Food, Agriculture and Enviromental. Vol.8 (3 \& 4) pp $610-613$

Padoavani RM, Lima LM, Colugnati FAB, Rodriguez Amaya DLB. 2007. Comparison of proximate, mineral and vitamin composition of common Brazilian and Us food.J.Food comp Anal 20;733-738

Perlas L and Gibson RS., 2002. Uses of soaking to enhance the bioavailability of iron and zinc from rize based complementary foods used in the Philippines. Journal of the Science of Food and Agriculture 82, 1115-1124

Ryan E, Galvink, O’ Connor TP, Maguire AR, O’Brien NM. 2007. Phytosterol, squalene, tocopherol content and fatty acid profile of selected seeds, grains, and legumes. Plant Foods HumNutr 62; 85-91

United States Department of Agriculture (USDA) (2010) USDA National Nutrient Database for Standard Reference

Wang, DW Hatcher, R., 2009. Influence of cooking and dehulling on nutritional composition of several varieties of lentils (Lens culinaris). Food Science and Technology 